\title{
PENGARUH KONSERVATISME AKUNTANSI DAN GOOD CORPORATE GOVERNANCE TERHADAP ASIMETRI INFORMASI
}

\author{
Indah Kurniyawati \\ Fakultas Ekonomi Universitas Islam Lamongan \\ indah@timeserve.co.id
}

\begin{abstract}
ABSTRAK
Penelitian ini bertujuan menguji pengaruh konservatisme akuntansi terhadap dan good corporate governance terhadap asimetri informasi. Penelitian ini dilakukan pada perusahaan manufaktur yang terdaftar di Buesa Efek Indonesia (BEI) dari tahun 2010 sampai tahun 2014. Asimetri informasi diukur dengan menggunakan CSPREAD, konservatisme akuntansi diukur dengan menggunakan accrual base sedangkan good corporate governance diukur dengan proporsi kepemilikan manajerial, proporsi kepemilikan institusional, komite audit, komisaris independen, ukuran dewan komisaris dan ukuran dewan direksi. Penelitian ini tidak mendukung penelitian yang dilakukan oleh Lafond dan Watts (2006) yang membuktikan bahwa konservatisme dapat menurunkan asimetri informasi. Selain itu penelitian ini juga tidak mendukung penelitian dari Komsiyah (2003) yang menjelaskan dalam penelitiannya bahwa hubungan antara good corporate governance dan pengungkapan informasi untuk menghindari asimetri informasi.
\end{abstract}

Kata kunci : konservatisme, asimetri informasi, accrual base, spread, good corporate governance

\section{PENDAHULUAN}

Konservatisme adalah prinsip dasar akuntansi yang telah banyak dianut oleh para akuntan sejak abad ke15 dan penggunanannya semakin popular dalam tiga dekade terakhir. FASB Statement of Concept No. 2 mendefinisikan konservatisme sebagai suatu reaksi kehati-hatian (prudent reaction) menghadapi ketidakpastian yang akan terjadi. Konservatisme yang diterapkan oleh perusahaan berbedabeda tergantung ketidakpastian dan resiko yang melekat pada setiap masing-masing unit bisnis perusahaan yang telah diperhitungkan sebelumnnya.

$$
\text { Dalam penerapan prinsip }
$$
konservatisme terdapat pro dan kontra. Pengkritik konservatisme menganggap bahwa prinsip ini dapat mengakibatkan laporan keuangan menjadi bias sehingga laporan keuangan tersebut tidak dapat digunakan sebagi alat untuk mengevaluasi resiko dari perusahaan. Pendapat ini didukung oleh Monahan (1999) dalam Dwiputranto (2009) yang menyatakan bahwa semakin tinggi tingkat konservatisme pada suatu laporan, maka nilai buku yang 
dilaporkan akan semakin bias. IFRS merupakan wujud adanya penolakan dan kritik terhadap prinsip konservatisme akuntansi karena prinsip fair value lebih menekankan pada relevansi. Sejak tahun 2010 prinsip konservatisme akuntansi diganti dengan prudence / kehati - hatian yang penilaiannya lebih ke arah current value. Prudence pada dasarnya hampir sama dengan konservatisme akuntansi, hanya saja lebih menekankan pada kehati - hatian dalam pelaksanan penilaian yang dibutuhkan untuk membuat perkiraan yang sangat diperlukan. Yang dimaksud dengan prudence dalam IFRS, terutama sehubungan dengan pengakuan pendapatan adalah pendapatan boleh diakui meskipun masih berupa potensi, sepanjang memenuhi ketentuan pengakuan pendapatan dalam IFRS.

Penelitian yang medukung konservatisme adalah LaFond dan Watts (2006) mengungkapkan bahwa laporan keuangan yang telah menggunakan prinsip konservatisme dapat mengurangi kemungkinan pihak manager melakukan manipulasi laporan keuangan serta mengurangi deadweight loss (biaya agensi) yang timbul sebagai akibat dari asimetri informasi. Oleh sebab itu, salah satu cara yang dapat dilakukan untuk mencegah adanya manipulasi terhadap laporan keuangan adalah dengan penerapan prinsip akuntansi yang konservatif. LaFond dan Watts (2006) dalam penelitian mereka menjelaskan bahwa laporan keuangan yang menerapkan prinsip konservatisme dapat mencegah asimetri informasi dengan cara membatasi pihak manajemen melakukan manipulasi laporan keuangan.

Kepemilikan seorang manajer akan menentukan kebijakan dan pengambilan keputusan terhadap metode akuntansi yang diterapkan dalam perusahaan. Warfield et al., (1995) menyatakan adanya hubungan positif antara kepemilikan manajerial dengan kandungan informasi dalam laba.

Kepemilikan institusional memiliki kemampuan untuk mengendalikan pihak manajemen melalui proses monitoring secara efektif. Persentase tertentu yang dimiliki oleh institusi dapat mempengaruhi proses penyusunan laporan keuangan yang tidak menutup kemungkinan terdapat akrualisasi sesuai kepentingan pihak manajemen (Gideon, 2005). Cornet et al., (2006) 
menyimpulkan bahwa tindakan pengawasan perusahaan oleh pihak investor institusional dapat mendorong manajer untuk lebih memfokuskan perhatiannya terhadap kinerja perusahaan sehingga akan mengurangi perilaku opportunistic atau mementingkan diri sendiri.

Secara umum dewan komisaris ditugaskan dan juga diberikan tanggung jawab atas pengawasan terhadap kualitas informasi yang terkandung dalam laporan keuangan. Hal ini sangat penting mengingat adanya kepentingan dari para manajemen untuk menyampaikan informasi yang kurang transparan yang akan berdampak pada berkurangnya kepercayaan investor. Untuk mengatasinya dewan komisaris diperbolehkan untuk memiliki akses pada informasi perusahaan. Dewan komisaris tidak memiliki otoritas dalam perusahaan, makas dewan direksi bertanggung jawab untuk menyampaikan informasi yang terkait dengan aktivitas perusahaan terhadap dewan komisaris (NCCG, 2001). Selain untuk mensupervisi dan memberikan nasehat kepada dewan direksi sesuai dengan UU No. 1 tahun 1995, fungsi dewan komisaris yang lain sesuai dengan yang dinyatakan dalam National
Code for Good Corporate Governance 2001 adalah memastikan bahwa perusahaan telah melakukan tanggung jawab sosial dan mempertimbangakan kepentingan berbagai stakeholder perusahaan sebaik memonitor efektifitas pelaksanaan good corporate governance.

Beasley (1996) menyarankan bahwa masuknya dewan komisaris yang berasal dari luar perusahaan dapat meningkatkan efektivitas dewan tersebut dalam mengawasi menajemen untuk mencegah kecurangan dalam pelaporan keuangan yang secara langsung dapat menghindarkan dari asimetri informasi dalam perusahaan. Hasil penelitian yang dilakukan oleh Beasly (1996) juga melaporkan bahwa komposisi dewan komisaris lebih penting untuk mengurangi terjadinya kecurangan pelaporan keuangan. Analisis lain dalam penelitian ini menunjukkan bahwa karakteristik komisaris yang berasal dari luar perusahaan juga berpengaruh terhadap kecenderungan terjadinya kecuranga pelaporan keuangan.

Beasly (1996) melaporkan dalam penelitiannya bahwa pengaruh ukuran dewan komisaris terhadap kecurangan dalam pelaporan keuangan adalah 
positif secara signifikan. Untuk itu penelitian ini mendukung bahwa dewan komisaris yang lebih banyak kurang efektif dalam melakukan pengendalian terhadap manajemen.

Ukuran dan komposisi dewan direksi dapat mempengaruhi efektif tidaknya aktivitas monitoring. Ukuran dewan yang besar menguntungkan perusahaan dari sudut pandang resource dependence yaitu bahwa perusahaan akan tergantung dengan dewannya untuk dapat mengelola sumber dayanya secara lebih baik. S. Beiner et al., (2003) menegaskan bahwa dewan direktur merupakan mekanisme governance yang penting, karena dewan direksi dapat memastikan bahwa manajer mengikuti kepentingan para dewan direksi. Dewan direksi bertanggung jawab penuh atas pengurusan perusahaan dalam dua hal yaitu untuk kepentingan dan tujuan perusahaan serta mewakili perusahaan baik di dalam maupun diluar pengadilan.

Keberadaan komite audit sangatlah penting terdahap tata kelola perusahaan. Komite audit dianggap sebagai penghubung antara pemegang saham dan dewan komisaris dengan para manajemen perusahaan dalam mengatasi masalah pengendalian. Berdasarkan Surat Edaran BEJ, SE008/BEJ/12-2001, keanggotaan komite audt terdiri dari sekurang - kurangnya tiga orang termasuk ketua komite audit. Utama dan Leonardo (2006) memberikan bukti empiris tentang damoak komposisi komite audit dan kendali dari pengelola perusahaan pada efektivitas komite audit berdsarkan survey atas komite audit perusahaan yang listing di BEJ. Mereka menemukan bukti bahwa komposisi komite audit memiliki dampak positif yang signifikan dalam efektivitas komite audit.

Berdasarkan latar belakang di atas, tujuan dari penelitian ini adalah untuk mengetahui dan menganalisa pengaruh konservatisme akuntansi terhadap asimetri informasidan juga mengetahui dan menganalisa pengaruh good corporate governance terhadap asimetri informasi

\section{TINJAUAN PUSTAKA}

\subsection{Konservatisme Akuntansi}

Definisi konservatisme berdasarkan glossary dalam FASB Statement of Concept No. 2 adalah reaksi yang hati-hati terhadap ketidakpastian dengan mencoba 
meyakinkan bahwa ketidakpastian dan resiko yang melekat dalam kondisi bisnis cukup layak untuk dipertimbangkan. Statement No. 2 tersebut menegaskan bahwa pelaporan yang hati-hati (konservatif) tersebut didasarkan pada pengembangan kepercayaan yang hati-hati terhadap hasil di masa mendatang yang terlepas dari perbedaan kepentingan yang disajikan oleh manajemen.

Sari (2004) menyatakan bahwa konservatisme adalah prinsip untuk melaporkan informasi akuntansi yang terendah dari beberapa kemungkinan nilai untuk aktiva dan pendapatan serta yang tertinggi dari beberapa kemungkinan nilai kewajiban dan beban.

Wolk et al (2001: 144-145) mendefinisikan konservatisme akuntansi sebagai usaha untuk memilih metode akuntansi berterima umum yang (a) memperlambat pengakuan revenue, (b) mempercepat pengakuan expenses, (c) merendahkan penilaian aktiva, dan (d) meninggikan penilaian utang. Definisi tersebut mengakibatkan nilai aktiva bersih yang understated secara persisten.

Konservatisme, dari sudut pandang manajemen didefinisikan sebagai metode akuntansi berterima umum yang melaporkan aktiva dengan nilai terendah, kewajiban dengan nilai tertinggi, menunda pengakuan pendapatan, serta mempercepat pengakuan biaya. Definisi ini menunjukkan bahwa akuntansi konservatif tidak saja berkaitan dengan pemilihan metode akuntansi, tetapi juga estimasi yang mengakibatkan nilai buku aktiva menjadi lebih rendah (Wolk, 2001; Penman dan Zhang, 2002).

Konservatisme adalah tidak mengantisipasi laba tetapi mengantisipasi semua kerugian. Menurut Watts (2003), mengantisipasi laba berarti mencatat laba sebelum ada klaim secara hukum dihubungkan dengan aliran kas dimasa yang akan datang dan sebaliknya tidak mengantisipasi laba berarti belum mencatat laba sebelum ada klaim secara hukum dihubungkan dengan aliran kas dimasa yang akan datang.

Sedangkan literatur akademik menginterpretasikan konservatisme sebagai kecenderungan akuntan yang mengharuskan tingkat verifikasi yang lebih tinggi untuk mengakui good news sebagai keuntungan dari pada bad news sebagai kerugian (Basu,1997). Menurut Basu (1997), konservatisme adalah 
masalah pengakuan bad news yang lebih awal dari pada good news dalam laba. Anggapan bahwa return saham saat ini efisien karena return saham ini masih mengandung oleh good news atau bad news tentang harapan aliran kas perusahaan di masa yang akan datang.

Konservatisme merupakan salah satu prinsip akuntansi yang paling mempengaruhi dalam penilaian akuntansi (Sari, 2004). Tetapi kinservatisme juga merupakan suatu prinsip yang kontroversial.

Pemikiran maupun bukti - bukti empiris masih menunjukkan adaya kontroversi mengenai angka yang terdapat dalam akuntansi yang masih konservatif.

Meskipun prinsip konservatisme telah diakui sebagai dasar laporan keuangan di Amerika Serikat, namun beberapa peneliti masih meragukan manfaat konservatisme. Konservatisme dianggap sebagai sistem akuntansi yang bias. Pendapat ini dipicu oleh definisi akuntansi yang mengakui cost dan kerugian lebih cepat, mengakui pendapatan dan keuntungan lebih lambat, menilai aktiva dengan nilai yang terendah, dan kewajiban dengan nilai yang tertinggi (Basu, 1997).

Senada dengan pendapat tersebut adalah pendapat Penman dan Zhang
(2002), dan Felthem dan Ohlson (1995) yang memperkirakan bahwa konservatisme menghasilkan kualitas laba yang rendah, dan kurang relevan. Konservatisme mempengaruhi kualitas angka-angka yang dilaporkan di neraca maupun laba dalam laporan laba rugi. Ketika perusahaan meningkatkan jumlah investasi, maka akuntansi konservatif akan menghasilkan perhitungan laba yang lebih rendah dibandingkan akuntansi optimis. Akuntansi konservatif juga akan menciptakan cadangan yang tidak tercatat, sehingga memungkinkan manajemen lebih leluasa melaporkan angka laba dimasa datang.

Pendukung konservatisme menyatakan bahwa konservatisme menyajikan laba dan aktiva dengan prinsip menunda pengakuan keuntungan dan secepatnya mengakui adanya kerugian. Prinsip ini memang akan menyebabkan laba dan aktiva periode berjalan menjadi lebih rendah. Bila terjadi kenaikan laba dan aktiva di masa datang akibat penerapan prinsip ini, hal tersebut disebabkan oleh keuntungan yang semula ditunda pengakuannya, telah diakui oleh perusahaan karena dipastikan akan terealisasi. Jadi bukan berarti peningkatan laba dan aktiva 
masa datang merupakan cermin dari tidak konservatifnya perusahaan (Watts, 2003). Pendukung konservatisme juga menyatakan bahwa laporan keuangan yang disusun dengan cara yang konservatif akan menyajikan informasi sesungguhnya dari nilai perusahaan. Sehingga akan membantu investor dan kreditor dalam pengambilan keputusan investasi.

Givoly dan Hayn (2000) menunjukan telah terjadi peningkatan konservatisme di Amerika Serikat. Akuntansi konservatif akan menguntungkan dalam konrak-kontrak antara pihak-pihak dalam perusahaan maupun dengan luar perusahaan. Konservatisme dapat membatasi tindakan manajer untuk membesarbesarkan laba serta memanfaatkan informasi yang asimetri ketika mengahadapi klaim atas aktiva perusahaan.

Penelitian yang dilakukan oleh Penman dan Zhang (2000) menyatakan bahwa konservatisme justru menyebabkan kualitas laba menjadi rendah. Hal ini disebabkan karena akuntansi konservatif akan langsung menyebabkan biaya investasi pada periode berjalan yang menyebabkan laba menjadi lebih rendah dan tercipta hidden reserve (cadangan tersembunyi). Bila pada tahun berikutnya perusahaan menurunkan biaya investasinya, maka akan terjadi likuidasi cadangan tersembunyi sehingga laba menjadi lebih tinggi.

Watts (2003) menyatakan bahwa eksistensi konservatisme penting dalam laporan keuangan. Ia mengatakan bahwa ada empat masalah yang mendorong penggunaan konservatisme. Empat masalah tersebut adalah :

1) Kontrak (contracting)

2) Tuntutan Hukum (litigation)

3) Perpajakan (taxation)

4) Peraturan (regulation)

Terdapat beberapa cara untuk mengukur tingkat konservatisme yang pernah digunakan dalam berbagai penelitian. Watts (2003) membagi konservatisme menjadi 3 pengukuran, yaitu Earning/ Stock Return Relation Measure, Earning / Accrual Measures dan Net Asset Measure. Dalam penelitian ini menggunakan Earnings/Accrual Measures. Model Givoly dan Hayn (2000). Model pengukuran ini memfokuskan efek konservatisme pada laporan laba rugi selama tahun berjalan. Givoly dan Hyan (2000) berpendapat bahwa konservatisme menghasilkan akrual 
negatif yang terus menerus. Akrual yang dimaksud adalah perbedaan antara laba bersih sebelum depresiasi/amortisasi dan arus kas kegiatan operasi. Semakin besar akrual negatif maka akan semakin konservatif akuntansi yang diterapkan. Sebaliknya laporan keuangan yang optimis akan cenderung memiliki laba bersih yang lebih tinggi dibandingkan arus kas operasi sehingga akrual yang dihasilkan adalah positif. Dalam penelitian ini, menggunakan model pengukuran Givoly dan Hayn (2000). Givoly dan Hayn (2000) mengukur konservatisme akuntansi dengan cara mengurangkan income before extraordinary item dengan arus kas operasi dan ditambahkan dengan beban depresiasi.

\subsection{Asimetri Informasi}

Asimetri informasi merupakan suatu keadaan dimana manajer memiliki akses informasi atas prospek perusahaan yang tidak dimiliki oleh pihak luar perusahaan.

Jensen dan Meckling (1976), menyatakan perusahaan (Corporate) sebagai sebuah kolektivitas dari banyak kepentingan telah memunculkan sebuah pertanyaan yaitu apakah benar manajemen dalam menjalankan perusahaan selaras dengan kepentingan pemegang saham dan stakeholders yang lainya. Manajemen lebih banyak mengetahui prospek usaha yang sebenarnya dibanding dengan pemegang saham, dengan kata lain telah terjadi penguasaan informasi yang berbeda (asymmetric information).

Menurut Scott (2000) ada dua jenis asymmetric information yaitu:

\section{a. Adverse Selection}

Adverse selection adalah jenis asimetri informasi dalam mana satu pihak atau lebih yang melangsungkan/akan melangsungkan suatu transaksi usaha, atau transaksi usaha potensial memiliki informasi lebih atas pihak-pihak lain. Adverse selection terjadi karena beberapa orang seperti manajer perusahaan dan para pihak dalam (insider) lainnya lebih mengetahui kondisi kini dan prospek ke depan suatu perusahaan dari pada para investor. Ketimpangan pengetahuan informasi perusahaan ini dapat menimbulkan masalah dalam transaksi pasar modal karena investor tidak mempunyai informasi yang cukup dalam pengambilan keputusan investasinya.

b. Moral Hazard 
Moral hazard adalah jenis asimetri informasi dalam mana satu pihak atau lebih yang melangsungkan atau akan melangsungkan suatu transaksi usaha atau transaksi usaha potensial dapat mengamati tindakantindakan mereka dalam penyelesaian transaksi-transaksi mereka sedangkan pihak lainnya tidak. Moral hazard dapat terjadi karena adanya pemisahan pemilikan dengan pengendalian yang merupakan karakteristik kebanyakan perusahaan besar. Dengan kata lain terjadi karena pihak-pihak di luar perusahaan (investor) mendelegasikan tugas dan kewenangannya kepada manajer tetapi investor tidak dapat sepenuhnya memantau manajer dalam melaksanakan pendelegasian tersebut.

Informasi akuntansi yang berkualitas merupakan hal yang penting untuk menurunkan tingkat asimetri informasi, hal ini dikarenakan adanya asimetri informasi menyebabkan stakeholders sebagai pihak eksternal tidak dapat mengamati dan mengawasi seluruh kinerja dan prospek perusahaan seutuhnya. Oleh karena itu, keberadaan dari asimetri informasi ini dipercaya sebagai penyebab dari timbulnya praktek manajamen laba (earning management). Richardson (1998) berpendapat bahwa terdapat sebuah hubungan sistematik antara besarnya asimetri informasi dengan tingkat manajemen laba. Fleksibilitas manajemen untuk memanage earning dapat dikurangi dengan menyediakan informasi akuntansi yang lebih berkualitas bagi pengguna eksternal.

Teori agensi menjelaskan tentang hubungan kontraktual antara pihak yang mendelegasikan keputusan tertentu (prinsipal/pemilik/pemegang saham) dengan pihak yang menerima pendelegasian tersebut (agen/direksi/manajemen) (Jensen \& Meckling, 1976). Dalam teori agensi diasumsikan terdapat kemungkinan konflik dalam hubungan antara prinsipal dan agen (agency conflict), konflik yang timbul sebagai akibat keinginan manajemen (agen) untuk melakukan tindakan yang sesuai dengan kepentingannya dapat mengorbankan kepentingan pemegang saham (prinsipal) untuk memperoleh return dan nilai jangka panjang perusahaan.

Masalah agensi antara pemegang saham sebagai prinsipal dan manajer sebagai agen yang diberi mandat, karena apa yang dilakukan manajer sulit diketahui oleh pemegang saham sebagai prinsipal disini muncul adanya moral 
hazard, yaitu tindakan manajer yang cenderung menyimpang dari keinginan pemilik (Padilla, 2003). Hal ini kemungkinan manajer bekerja tidak maksimal di perusahaan karena ; (1) manajer mempunyai kegiatan lain yang bersifat pribadi, tetapi dikerjakan di perusahaan, (2) manajer menggunakan fasilitas perusahaan seperti mobil dan fasilitas lain untuk kepentingan pribadi, (3) manajer melakukan praktek mark up dalam pengadaan barang yang kualitasnya lebih jelek dengan harga yang lebih murah untuk mendapatkan keuntungan pribadi. Kondisi ini terjadi karena pemegang saham sebagai prinsipal sulit untuk mendeteksi apa yang sesungguhnya dilakukan oleh manajer.

Agency conflict timbul pada berbagai hal sebagai berikut : (Jensen \& Meckling, 1976, Jensen, 1986, Alijoyo \& Zaini, 2004).

1. Manajemen memilih investasi yang paling sesuai dengan kemampuan dirinya dan bukan yang paling menguntungkan bagi perusahaan. Misalnya, investasi yang bisa meningkatkan nilai individu manajer walaupun biaya penugasannya tinggi sehingga para manajer akan berada pada posisi untuk mengekstrak tingkat remunerasi yang lebih tinggi dari perusahaan (Moral-Hazard).

2. Manajemen cenderung mempertahankan tingkat pendapatan perusahaan yang stabil, sedangkan pemegang saham lebih menyukai distribusi kas yang lebih tinggi melalui beberapa peluang investasi internal yang positif (internal positive investment opportunities) (Earning Retention)

3. Manajemen cenderung mengambil posisi aman untuk mereka sendiri dalam mengambil keputusan investasi. Dalam hal ini, mereka akan mengambil keputusan investasi yang sangat aman dan masih dalam jangkauan kemampuan manajer. Mereka akan menghindari keputusan investasi yang dianggap menambah risiko bagi perusahaannya walaupun mungkin hal itu bukan pilihan terbaik bagi perusahaan (Risk Aversion).

4. Manajemen cenderung hanya memperhatikan cash flow perusahaan sejalan dengan waktu penugasan mereka. Hal ini dapat menimbulkan bias dalam pengambilan keputusan yaitu berpihak pada proyek jangka pendek dengan pengembalian akuntansi yang tinggi (short term 
high accounting return project) dan kurang atau tidak berpihak pada proyek jangka panjang dengan pengembalian NPV positif yang jauh lebih besar (Time-Horizon).

5. Asumsi dasar lainnya yang membangun agency theory adalah agency problem yang timbul sebagai akibat adanya kesenjangan antara kepentingan pemegang saham sebagai pemilik dan manajemen sebagai pengelola. Pemilik memiliki kepentingan agar dana yang diinvestasikannya mendapatkan return maksimal, sedangkan manajer berkepentingan terhadap perolehan insentif atas pengelolaan dana pemilik (agency problem).

\subsection{Corporate Governance}

Dua teori utama yang terkait dengan corporate governance adalah stewardship theory dan agency theory (Chinn, 2000; Shaw, 2003 dalam Kaihatu, 2006). Stewardship theory dibangun diatas asumsi filosofis mengenai manusia yakni manusia yang pada hakikatnya dapat dipercaya, mampu bertindak dengan penuh tanggung jawab, memiliki integritas dan kejujuran terhadap pihak lain.
Stewardship theory memandang manajemen sebagai pihak yang dapat dipercaya untuk bertindak dengan sebaik-baiknya bagi kepentingan publik maupun shareholders. Sedangkan agency theory memandang bahwa manajemen perusahaan sebagai agen bagi para pemegang saham yang akan bertindak dengan penuh kesadaran untuk kepentingan atau keuntungannnya sendiri (Jensen dan Meckling, 1976). Teori ini memandang manajer bukan sebagai pihak yang arif dan bijaksana serta adil terhadap pemegang saham. Berbagai pemikiran mengenai corporate governance berkembang dengan bertumpu pada agency theory.

Apabila sistem hukum lemah, maka diperlukan sinyal yang memiliki kredibilitas tinggi dan yang dapat mengindikasikan bahwa perusahaan menganggap kebutuhan para investor merupakan hal yang penting (Coffee, 2001). Corporate Governance berkaitan dengan bagaimana para investor yakin bahwa manajer akan memberikan keuntungan bagi mereka, yakin bahwa manajer tidak akan menggelapkan atau menginvestasikan dana yang telah ditanamkan oleh investor ke dalam proyek-proyek yang tidak menguntungkan, dan juga berkaitan 
dengan bagaimana cara investor mengontrol manajer.

Bernhart dan Rosenstein (1998, dalam Siallagaan \& Mas'ud, 2006) menyatakan beberapa mekanisme (mekanisme corporate governance) seperti mekanisme internal, seperti struktur dan dewan komisaris, serta mekanisme eksternal seperti pasar untuk kontrol perusahaan diharapkan dapat mengatasi masalah keagenan. Konflik keagenan yang mengakibatkan adanya sifat opportunistic manajemen akan mengakibatkan rendahnya kualitas laba. Rendahnya kualitas laba akan dapat membuat kesalahan pembuatan keputusan kepada para pemakainya seperti para investor dan kreditor, sehingga nilai perusahaan akan berkurang.

Adapun mekanisme corporate governance antara lain :

1. Proporsi Kepemilikan Manajerial

Pemahaman terhadap kepemilikan perusahaan sangat penting karena berkaitan dengan pengendalian operasional perusahaan. Dari sudut pandang teori akuntansi, manajemen laba sangat ditentukan oleh motivasi manajer perusahaan. Motivasi yang berbeda menghasilkan besaran manajemen laba yang berbeda, seperti antara manajer yang juga sekaligus sebagai pemegang saham dan manajer yang tidak sebagai pemegang saham. Hal ini sesuai dengan sistem pengelolaan perusahaan dalam dua kriteria : (a) perusahaan dipimpin oleh manajer dan pemilik (owner-manager); (b) perusahaan yang dipimpin oleh manajer non pemilik (non-ownermanager). Dua kriteria ini akan mempengaruhi manajemen laba, sebab kepemilikan seorang manajer akan ikut menentukan kebijakan dan pengambilan keputusan terhadap metode akuntansi yang diterapkan pada perusahaan yang mereka kelola. Secara umum dapat dikatakan bahwa persentase tertentu kepemilikan saham oleh pihak manajemen cenderung mempengaruhi tindakan manajemen laba (Boediono, 2005).

Jensen dan Meckling (1976) menyatakan bahwa untuk meminimalkan konflik keagenan adalah dengan meningkatkan kepemilikan manajerial di dalam perusahaan. Siallagaan dan Mas'ud (2006) menyatakan bahwa dengan kepemilikan manajerial dalam perusahaan maka manajemen akan cenderung untuk berusaha meningkatkan kinerjanya untuk kepentingan pemegang saham 
dan untuk kepentingannya sendiri. Sensitivitas manajemen terhadap pengaruh para pemegang saham akan tergantung pada tingkat kontrol kepemilikan manajerial. Manajemen dengan kontrol kepemilikan yang besar memiliki insentif yang lebih rendah untuk melakukan self-serving behaviour yang tidak meningkatkan nilai perusahaan dan bisa jadi memiliki lebih banyak kecenderungan untuk menerapkan kebijakan akuntansi konservatisme untuk meningkatkan kualitas laba (Amalia, 2007).

2. Proporsi Kepemilikan

Institusional

Melalui kepemilikan institusional, efektivitas pengelolaan sumber daya perusahaan oleh manajemen dapat diketahui dari informasi yang dihasilkan melalui reaksi pasar atas pengumuman laba. Kepemilikan institusional memiliki kemampuan untuk mengendalikan pihak manajemen melalui proses monitoring secara efektif sehingga mengurangi tindakan manajemen melakukan manajemen laba. Persentase saham tertentu yang dimiliki oleh institusi dapat mempengaruhi proses penyusunan laporan keuangan yang tidak menutup kemungkinan terdapat akrualisasi sesuai kepentingan

pihak manajemen.(Boediono, 2005).

Kepemilikan institusional umumnya bertindak sebagai pihak yang memonitor perusahaan. Faisal (2004) menyatakan bahwa perusahaan dengan kepemilikan institusional yang besar (lebih dari 5\%) mengindikasikan kemampuannya untuk memonitor manajemen. Semakin besar kepemilikan institusional maka semakin efisien pemanfaatan aktiva perusahaan.

Ujiyantho dan Bambang (2007) menyimpulkan bahwa tindakan pengawasan perusahaan oleh pihak investor institusional dapat mendorong manajer untuk lebih memfokuskan perhatiannya terhadap kinerja perusahaan sehingga akan mengurangi perilaku opportunistic atau mementingkan diri sendiri.

3. Dewan Komisaris Independen

Kemampuan dewan komisaris untuk mengawasi merupakan fungsi yang positif dari porsi dan independensi dari dewan komisaris eksternal. Dewan komisaris juga bertanggung jawab atas kualitas laporan yang disajikan.

Dewan Komisaris memegang peranan yang sangat penting dalam perusahaan, terutama dalam pelaksanaan Good Corporate 
Governance. Menurut Egon Zehnder, Dewan Komisaris - merupakan inti dari Corporate Governance - yang ditugaskan untuk menjamin pelaksanaan strategi perusahaan, mengawasi manajemen dalam mengelola perusahaan, serta mewajibkan terlaksananya akuntabilitas. Pada intinya, Dewan Komisaris merupakan suatu mekanisme mengawasi dan mekanisme untuk memberikan petunjuk dan arahan pada pengelola perusahaan. Mengingat manajemen yang bertanggung jawab untuk meningkatkan efisiensi dan daya saing perusahaan - sedangkan Dewan Komisaris bertanggung jawab untuk mengawasi manajemen - maka Dewan Komisaris merupakan pusat ketahanan dan kesuksesan perusahaan. (Egon Zehnder International, 2000 hal.12-13 dalam FCGI,2001).

Hal ini menuntut adanya individuindividu dengan kualitas yang luar biasa baik, memiliki latar belakang yang beragam, berbekal keahlian utama dan pemahaman yang serius tentang perusahaan dan bisnis. Fungsi service dan control dewan komisaris sebagai mekanisme corporate governance ini dapat dilihat sebagai suatu sinyal kepada para investor bahwa perusahaan telah dikelola sebagaimana mestinya. Investor diharapkan akan menerima sinyal ini dan bersedia membayar premium yang lebih tinggi untuk perusahaan yang well-governed di Indonesia (Amalia, 2007).

4. Ukuran Dewan Komisaris

Dewan komisaris bertugas melakukan pengawasan dan memberikan masukan kepada dewan direksi perusahaan. Dewan komisaris tidak memiliki otoritas langsung terhadap perusahaan. Fungsi utama dari dewan komisaris adalah mengawasi kelengkapan dan kualitas informasi laporan atas kinerja dewan direksi. Karena itu, posisi dewan komisaris sangat penting dalam menjembatani kepentingan principal dalam sebuah perusahaan.

Dengan semakin banyaknya anggota dewan komisaris, pengawasan terhadap dewan direksi jauh lebih baik, masukan atau opsi yang akan di dapat direksi akan jauh lebih banyak. Untuk itu masih diperlukan penelitian yang dapat membuktikan pengaruh ukuran dewan komisaris ini.

Jensen (1993) merupakan yang pertama menyimpulkan bahwa ukuran dewan komisaris merupakan bagian dari mekanisme corporate governance. 
Jensen juga menyatakan bahwa dewan komisaris yang ukurannya besar dianggap kurang efektif daripada dewan komisaris yang ukurannya kecil.

Penelitian yang dilakukan Yenmack (1996), Beaslley (1996) dan Jensen (1993) juga menyimpulkan bahwa dewan komisaris yang besar dianggap kurang efektif dalam menjalankan fungsinya karena sulit dalam komunikasi, koordinasi serta pembuatan keputusan.

\section{Ukuran Dewan Direksi}

Board size atau ukuran dewan direksi adalah jumlah dewan direksi dalam perusahaan, semakin banyak dewan direksi dalam perusahaan akan memberikan lebih banyak pengawasan terhadap kinerja perusahaan yang semakin lebih baik, dengan kinerja perusahaan yang baik dan terkontrol, maka akan menghasilkan profitabilitas yang baik dan nantinya dapat meningkatkan harga saham perusahaan dan nilai perusahaan pun juga akan ikut meningkat.

Beiner, et al (2003) menegaskan bahwa dewan direktur merupakan institusi ekonomi yang membantu memecahkan permasalahan agensi yang melekat dalam perusahaan publik. Dewan Direksi bertanggung jawab kepada komisaris (governance) perusahaan mereka. Dewan direktur bertugas untuk menjalankan manajemen perusahaan. Dewan direksi atau CEO harusnya terpisah dari anggota dewan komisaris. Ukuran dan komposisi dewan direksi dapat mempengaruhi efektif tidaknya aktivitas monitoring. Jumlah dewan direksi yang besar menguntungkan perusahaan dari sudut pandang resource deoendence yaitu bahwa perusahaan akan tergantung dengan dewannya untuk daat mengelola sumber dayanya secara lebih baik. Dewan direktur merupakan mekanisme governance yang paling penting, karena dewan direksi dapat memastikan bahwa manager mengikuti kepentingan dewan. Ketentuan jumlah minimal yang disyaratkan dalam peraturan UU No. 1 Tahun 1995 tentang Perseroan Terbatas (PT) yang harus dilaksanakan yaitu minimal untuk dewan direksi adalah 2 orang. Struktur corporate governance di Indonesia sesuai dengan UU No. 1 Tahun 1995 tentang Perseroan Terbatas, dimana Rapat Umum Pemegang Saham (RUPS) adalah bagian tertinggi yang terdiri atas pemegang saham yang memiliki hak memilih anggota dewan komisaris dan dewan direksi (Wulandari, 2006). Dewan direksi 
bertanggung jawab penuh atas pengurusan perusahaan dalan dua hal yaitu untuk kepentingan dan tujuan perusahaan serta mewakili baik di dalam maupun di luar perusahaan.

6. Keberadaan Komite Audit

Sesuai dengan Kep. 29/PM/2004, Komite audit adalah komite yang dibentuk oleh dewan komisaris untuk melakukan tugas pengawasan pengelolaan perusahaan. Keberadaan Komite Audit sangat penting bagi pengelolaan perusahaan. Komite audit merupakan komponen baru dalam sistem pengendalian perusahaan. Selain itu Komite audit dianggap sebagai penghubung antara pemegang saham dan dewan komisaris dengan pihak manajemen dalam menangani masalah pengendalian. Berdasarkan Surat Edaran BEJ, SE-008/BEJ/12-2001, keanggotaan komite audit terdiri dari sekurang - kurangnya tiga orang termasuk ketua komite audit. Anggota komite audit ini yang berasal dari komisaris hanya sebanyak satu orang, anggota komite yang berasal dari komisaris tersebut merupakan komisaris independen perusahaan tercatat sekaligus menjadi ketua komite audit. Anggota lain yang bukan merupakan komisaris independen harus berasal dari pihak eksternal yang independen (Nasution \& Dody, 2007).

Komite audit yang bertanggung jawab untuk mengawasi laporan keuangan, mengawasi audit eksternal, dan mengamati sistem pengendalian internal juga diharapkan dapat mengurangi sifat opportunistic manajemen yang melakukan manajemen laba.

\section{METODOLOGI PENELITIAN}

\subsection{Jenis Penelitian yang Digunakan}

Penelitian ini merupakan studi sebab - akibat (causal) karena penelitian ini diarahkan untuk mengetahui pengaruh konservatisma terhadap asimetri informasi dan pengaruh good corporate governance terhadap asimetri informasi.

\section{2 Objek Penelitian}

Penelitian ini menggunakan data skunder perusahaan manufaktur yang terdaftar di Bursa Efek Indonesia dan website masing - masing badan usaha. Pemilihan obyek penelitian ini diharapkan bisa menggambarkan persoalan penelitian yang telah dirumuskan dalam kerangka konseptual. Obyek penelitian yang akan diamati 
adalah laporan keuangan tahun 2010 sampai dengan tahun 2014.

\subsection{Populasi dan Sampel}

Populasi dalam penelitian ini adalah perusahaan publik sektor manufaktur yang telah terdaftar (listing) di BEI. Perusahaan manufaktur tersebut telah menerbitkan

dan mempublikasikan laporan tahunan selama 5 tahun berturut - turut, yaitu sejak tahun 2010 sampai dengan tahun 2014.

Sampel yang digunakan dalam penelitian ini adalah perusahaan manufaktur yang memiliki kriteria tertentu. Metode pengambilan sampel yang digunakan adalah purposive sampling dengan tujuan untuk mendapatkan sampel yang representatif sesuai dengan kriteria yang ditentukan. Dalam penelitian ini, peneliti menggunakan data time series dimana data tersebut sering disebut juga dengan data runtut waktu yaitu merupakan rangkaian observasi pada suatu nilai yang diambil pada waktu yang berbeda. Penelitian ini untuk melihat apakah terjadi korelasi antara suatu periode $t$ dengan periode sebelumnya ( $t-1)$. Secara sederhana adalah bahwa analisis regresi adalah untuk melihat pengaruh antara variabel independen terhadap variabel dependen.

Adapun kriterian yang digunakan dalam pemilihan sampel adalah sebagai berikut :

1. Perusahaan manufaktur yang sudah go publik yang terdaftar di BEI selama periode 2010 sampai dengan 2014

2. Data laporan keuangan perusahaan tersedia berturut turut untuk tahun pelaporan dari 2010 sampai dengan 2014

3. Perusahaan sampel tersebut mempublikasikan laporan keuangan auditor dengan menggunakan tahun buku yang berakhir pada tanggal 31 Desember dan mendapatkan opini wajar tanpa pengecualian

4. Data yang tersedia lengkap (data secara keseluruhan tersedia pada publikasi periode 31 Desember 2010 - 2014), baik data mengenai good corporate governance perusahaan dan data yang diperlukan untuk mendeteksi konservatisme akuntansi dan asimetri informasi

5. Perusahaan tidak mengalami transaksi merger, akuisisi, restruktirisasi dan perubahan kelompok usaha selama periode penelitian yaitu tahun 2010 - 2014 . 
Sebab hal tersebut dapat membuat hasil perhitungan menjadi bias.

\subsection{Variabel Penelitian dan Pengukurannya}

\section{Variabel Dependen}

Variabel dependen dalam penelitian ini adalah asimetri informasi. Asimetri informasi diukur dengan menggunakan bid - ask spread. Bid ask spread yang digunakan dalam penelitian ini adalah spread pasar yaitu merupakan selisih antara harga jual tertinggi (highest ask) dengan harga penawaran atau harga beli terendah (lowest bid) untuk saham tertentu.

Penelitian ini menggunakan persentase pengukuran spread seperti dibawah ini :

$$
\begin{gathered}
\text { \%spread }=(\text { ask price }- \text { bid price }) \\
((\text { ask price }+ \text { bid price }) / 2)
\end{gathered}
$$

Dalam penelitian ini harus memperhitungkan spread untuk periode announcement dan non announcement. Berdasarkan kanagaretnam et al. (20X)iit periode annauncemnet terdiri dari 5 hari periode perdagangan yaitu, 2 hari sebelum pengumuman dan 2 hari setelah pengumuman. Untuk menjamin periode non announcemnet tidak dipengaruhi oleh event study, maka penelitian ini dikeluarkan 10 hari sebelum dan 10 hari sesudah pengumuman laba. Selisih spread antara periode announcement dan non announcement dapat dilihat sebagai berikut :

\section{CSPREAD = selisih antara rata - rata persentase spread periode announcemnet dan non announcement}

\section{Variabel Independen}

Variabel independen dalam penelitian ini adalah konservatisme dan good corporate governance. Ukuran konservatisme yang dikembangkan oleh Givoly dan Hayn (2000) memfokuskan pada accrual base. Mereka mengukur konservatisme dengan cara mengurangkan income before extraordinary item dengan arus kas operasi dan ditambahkan dengan beban depresiasi.

Adapun rumus pengukurannya adalah :

\section{CONACCit $=$ Niit - CFOit}

CONACCit $=$ tingkat konservatisme perusahaan i pada tahun $\mathrm{t}$

= laba sebelum extraordinary item ditambah dengan depresiasi dari perusahaan i pada tahun $\mathrm{t}$

CFOit $=$ cash flow dari kegiatan operasi untuk perusahaan i pada tahun $\mathrm{t}$

Selanjutnya perhitungan CONACC tersebut akan dikalikan dengan -1, sehingga semakin tinggi 
CONACC akan menunjukkan konservatisme yang semakin tinggi pula.

Adapun komponen kedua dari variabel independen adalah good corporate governance. Mekanisme good corporate governance yang menjadi acuan penelitian ini adalah :

\section{Proporsi Kepemilikan Manajerial}

Proporsi kepemilikan manajerial diukur atau diproksikan dengan persentase jumlah kepemilikan saham oleh pihak manajemen perusahaan terhadap jumlah total saham yang beredar

2. Proporsi Kepemilikan Institusional

Proporsi kepemilikan institusional diukur atau diproksikan dengan persentase jumlah saham oleh pihak institusional terhadap jumlah saham yang beredar

3. Keberadaan Komite Audit

Keberadaan komite audit diukur atau diproksikan dengan informasi tentang keberadaan komite audit perusahaan dengan ketentuan :

Memiliki komite audit $\quad=1$

Tidak memiliki komite audit $=0$

4. Proporsi Komisaris Independen

Proporsi komisaris independen diukur atau diproksikan dengan persentase jumlah keanggotaan yang berasal dari luar perusahaan terhadap keseluruhan jumlah anggota dewan

5. Ukuran Dewan Komisaris

Ukuran dewan komisaris diukur atau diproksikan dengan banyaknya jumlah anggota dewan dalam perusahaan

6. Ukuran Dewan Direksi

Ukuran dewan direksi diukur atau diproksikan dengan banyaknya jumlah anggota dewan direksi

\section{Definisi Operasional}

Operasioanlisasi variabel ini diperluka untuk menentukan jenis dan indikator dari variabel - variabel yang terkait dalam penelitian ini. Selain itu proses ini juga dimaksudkan untuk menentukan skala pengukuran dari masing - masing variabel sehingga pengujian hipotesis dengan menggunakan alat bantu statistik dapat dilakukan dengan benar.

Dari penjelasan diatas dapat disajikan tabel Operasionalisasi Variabel sebagai berikut :

\section{Tabel 1. Operasionalisasi Variabel}

\begin{tabular}{|c|c|c|c|}
\hline Variabel & $\begin{array}{c}\text { Konsep } \\
\text { Variabel }\end{array}$ & Indikator & Skala \\
\hline $\begin{array}{l}\text { Variabel } \\
\text { Dependen : } \\
\text { Asmetri } \\
\text { Informasi }\end{array}$ & $\begin{array}{l}\text { Asimetri } \\
\text { informasi } \\
\text { merupakan } \\
\text { suatu kondisi } \\
\text { dimana } \\
\text { manajemen } \\
\text { memiliki } \\
\text { informasi yang } \\
\text { lebih banyak } \\
\text { dibandingkan } \\
\text { dengan pihak } \\
\text { lain (investor). }\end{array}$ & $\begin{array}{l}\text { Asimetri } \\
\text { informasi } \\
\text { diukur } \\
\text { dengan } \\
\text { menggunaka } \\
\text { n bid - ask } \\
\text { spread. Bid - } \\
\text { ask spread } \\
\text { yang } \\
\text { digunakan } \\
\text { dalam } \\
\text { penelitian ini }\end{array}$ & Rasio \\
\hline
\end{tabular}




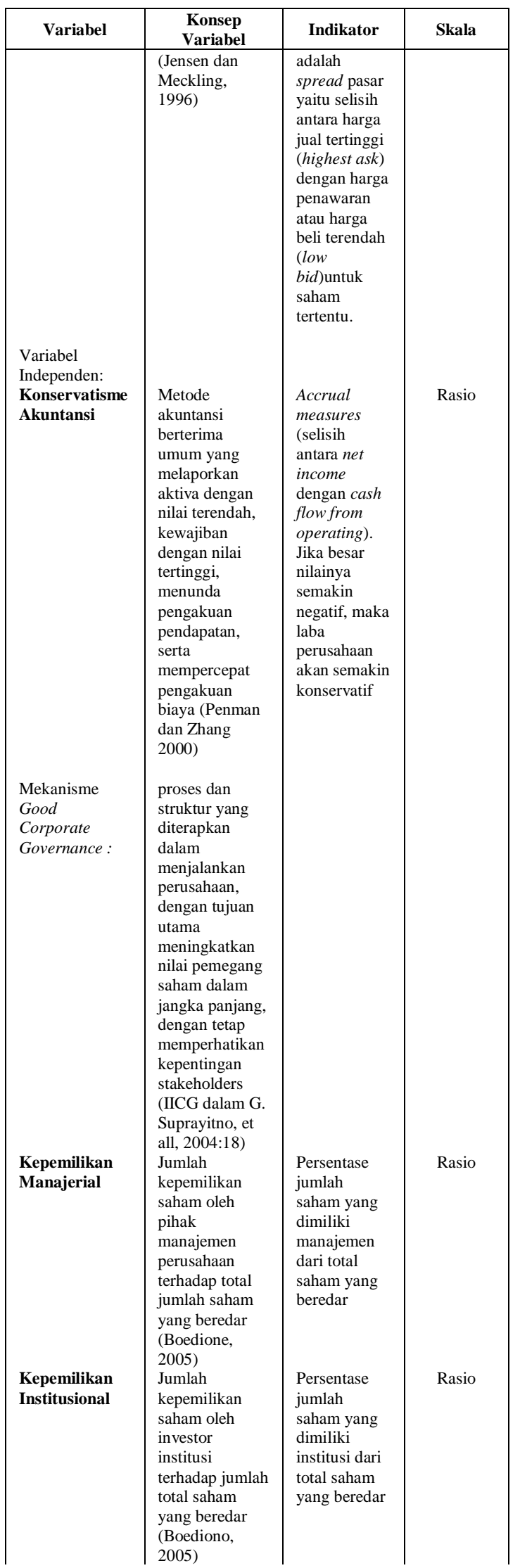

\begin{tabular}{|c|c|c|c|}
\hline Variabel & $\begin{array}{c}\text { Konsep } \\
\text { Variabel }\end{array}$ & Indikator & Skala \\
\hline Komite Audit & $\begin{array}{l}\text { Komite yang } \\
\text { bertanggung } \\
\text { jawab untuk } \\
\text { mengawasi } \\
\text { laporan } \\
\text { keuangan, } \\
\text { mengawasi } \\
\text { audit eksternal, } \\
\text { dan mengamati } \\
\text { sistem } \\
\text { pengendalian } \\
\text { intern } \\
\text { (termasuk audit } \\
\text { internal). } \\
\text { (Nasution dan } \\
\text { Dody, 2007) }\end{array}$ & $\begin{array}{l}\text { Informasi } \\
\text { tentang } \\
\text { keberadaan } \\
\text { komite audit } \\
\text { perusahaan } \\
\text { yang } \\
\text { tercancum } \\
\text { dalam } \\
\text { laporan } \\
\text { keuangan }\end{array}$ & $\begin{array}{l}\text { Variabel } \\
\text { dummy }\end{array}$ \\
\hline $\begin{array}{l}\text { Komisaris } \\
\text { Independen }\end{array}$ & $\begin{array}{l}\text { Jumlah } \\
\text { keanggotaan } \\
\text { komisaris yang } \\
\text { berasal dari luar } \\
\text { perusahaan } \\
\text { terhadap } \\
\text { keseluruhan } \\
\text { jumlah anggota } \\
\text { dewan } \\
\text { komisaris } \\
\text { (Beasly, 1996) }\end{array}$ & $\begin{array}{l}\text { Persentase } \\
\text { jumlah } \\
\text { anggota } \\
\text { dewan } \\
\text { komisaris } \\
\text { yang berasal } \\
\text { dari luar } \\
\text { perusahaan } \\
\text { dari seluruh } \\
\text { anggota } \\
\text { dewan } \\
\text { komisaris }\end{array}$ & Rasio \\
\hline $\begin{array}{l}\text { Ukuran Dewan } \\
\text { Komisaris }\end{array}$ & $\begin{array}{l}\text { Jumlah dewan } \\
\text { komisaris yang } \\
\text { ada dalam } \\
\text { perusahaan } \\
\text { (Jensen, 1993) }\end{array}$ & $\begin{array}{l}\text { Banyaknya } \\
\text { anggota } \\
\text { dewan } \\
\text { komisaris } \\
\text { dalam } \\
\text { perusahaan }\end{array}$ & Total \\
\hline $\begin{array}{l}\text { Ukuran Dewan } \\
\text { Direksi }\end{array}$ & $\begin{array}{l}\text { Jumlah dewan } \\
\text { direksi yang ada } \\
\text { dalam } \\
\text { perusahaan } \\
\text { (Beiner et al, } \\
\text { 2003) }\end{array}$ & $\begin{array}{l}\text { Banyaknya } \\
\text { anggota } \\
\text { dewan } \\
\text { direksi dalam } \\
\text { perusahaan }\end{array}$ & Total \\
\hline
\end{tabular}

\subsection{Teknik Analisis Data}

\section{Pengolahan Data}

Data yang telah dikumpulkan akan diolah dan dianalisis sebagai berikut :

1. Menyeleksi semua perusahaan manufaktur yang terdaftar di Bursa Efek Indonesia periode tahun 2010 2014 untuk mendapatkan sampel yang sesuai dengan kriteria yang telah diungkapkan diatas.

2. Menghitung proporsi kememilikan manajerial, proporsi kepemilikan institusional, keberadaan komite audit, proporsi komisaris 
independen, ukuran dewan komisaris dan ukuran dewan direksi untuk masing - masing perusahaan. Menghitung konservatisme akuntansi dengan mnggunakan rumus CONACCit dengan melihat data annual report perusahaan tersebut. Sedangkan untuk menghitung asimetri informasi dengan menggunakan pengukuran spread.

Penelitian ini menggunakan bantuan microsoft office excel 2011 dalam melakukan pengolahan data. Setelah melakukan prosedur pengolahan data maka data tersebut akan dianalisis menggunakan bantuan SPSS.

\section{Analisis Data}

Adapun tahapan - tahapan yang ditempuh oleh peneliti di dalam menganalisis data asalah sebagai berikut

\section{Analisis Statistik Deskritif}

Analisis data statistik paling sederhana adalah analisis statistik deskriptif. Analisis deskriptif adalah mengumpulkan, meringkas dan menyajikan data dalam bentuk yang mudah dibaca. Analisis ini akan digunakan untuk memberikan gambaran umum tentang perusahaan manufaktur yang terdaftar di Bursa
Efek Indonesia dan menjadi sampel penelitian.

2. Uji Lineritas dan Uji Asumsi Klasik

Sebelum analisis regresi dilakukan, terlebih dahulu dilakukan pengujian lineritas yaitu uji normalitas data dan uji asusmi klasik. Uji normalitas bertujuan untuk menguji apakah dalam model regresi, data yang digunakan memiliki distribusi normal atau tidak. Kurva yang menggambarkan distribusi normal adalah kurva normal yang berbentuk simetris. Untuk menguji apakah sampel penelitian merupakan jenis distribusi normal maka digunakan pengujian Kolmogorov - Smirnov Goodness of Fit Test terhadap residual model (Ghozali, 2002:74)

Uji asumsi klasik bertujuan untuk mengetahui apakah variabel dependen mampu diprediksi oleh variabel independennya. Dalam penelitian ini uji asumsi klasik harus dilakukan, agar dapat diketahui apakah data memenuhi asumsi klasik atau tidak. Hal ini untuk menghindari terjadinya estimasi yang bias mengingat tidak pada semua data dapat diterapkan regresi. Pengujian yang dilakukan adalah sebagi berikut 

a. Multikolineritas
b. Heterokedastisitas
c. Autokorelasi

\section{Uji Kesesuaian Model}

Dalam menguji hipotesis yang diajukan dalam penelitian ini digunakan analisis regresi linier. Berikut ini adalah model regresi untuk mengetahui adanya pengaruh konservatisme akuntansi terhadap asimetri informasi :

$\mathrm{Y}=\mathrm{a}+\mathrm{b}_{1} \mathrm{X}_{1}+\mathrm{e}$

CSPREADit $=\beta 0+\beta_{1}$ CONACCit $+€$

CSPREADit $=$ Asimetri informasi

CONACCit $=$ Tingkat konservatisme perusahaan i pada tahun $\mathrm{t}$

Model regresi untuk mengetahui adanya pengaruh good corporate governance terhadap asimetri informasi adalah :

$\mathrm{Y}=\mathrm{a}+\mathrm{b} 1 \mathrm{X} 1+\mathrm{b} 2 \mathrm{X} 2+\mathrm{b} 3 \mathrm{X} 3+\mathrm{b} 4 \mathrm{X} 4+\mathrm{b} 5 \mathrm{X} 5+$ b6X6 + e

CSPREADit $=\beta 0+\beta 1$ PKMit $+\beta 2$ PKIit + $\beta 3$ KKAit $+\beta 4$ PDKit $+\beta 5$ UDKit $+\beta 6$ UDSit $+€$

CSPREAD it $=$ Asimetri informasi

PKMit = Proporsi komisaris manajerial

PKIit = Proporsi komisaris institusional

KKAit $=$ Keberadaan komite audit

PDKit = Proporsi komisaris idependen

UDKit = Ukuran dewan komisaris

UDSit = Ukuran dewan direksi

\section{ANALISIS DAN PEMBAHASAN} HASIL PENELITIAN

\subsection{Gambaran Umum Obyek Penelitian}

Penelitian ini, perusahaan yang dijadikan obyek penelitian adalah Perusahaan Manufaktur yang terdaftar di Bursa Efek Indonesia (BEI) selama periode penelitian yaitu tahun 2010 sampai tahun 2014. Populasi perusahaan manufaktur yang terdaftar selama periode penelitian adalah 640 sampel perusahaan. Berdasarkan kriteria yang telah diterapkan diperoleh sampel sebanyak 585 sampel perusahaan, atau 117 perusahaan per tahun. Adapun datanya dapat dilihat pada tabel 4.1.

Tabel 2.Tabel Populasi

\begin{tabular}{|c|c|}
\hline Tabel Populasi & Jumlah \\
\hline Kriteria 1 & \\
Perusahaan manufaktur yang sudah & \\
go publik yang terdaftar di & \\
BEI selama periode 2010 & \\
sampai dengan 2014 & \\
Kriteria 2 & \\
Data laporan keuangan perusahaan & \\
tersedia berturut turut untuk & \\
tahun pelaporan dari 2010 & \\
sampai dengan 2014 & \\
Kriteria 3 & \\
Perusahaan sampel tersebut & \\
mempublikasikan laporan & \\
keuangan auditor dengan & \\
menggunakan tahun buku & \\
yang berakhir pada tanggal & \\
31 Desember ran dan & \\
mendapatkan opini wajar & \\
tanpa pengecualian & \\
Kriteria 4 & \\
Data yang tersedia lengkap (data & \\
secara keseluruhan tersedia \\
pada publikasi periode 31 \\
Desember 2010 - 2014), baik \\
data mengenai good
\end{tabular}




\begin{tabular}{|c|c|}
\hline Tabel Populasi & Jumlah \\
\hline $\begin{array}{l}\text { corporate governance } \\
\text { perusahaan dan data yang } \\
\text { diperlukan untuk mendeteksi } \\
\text { konservatisme akuntansi dan } \\
\text { asimetri informasi }\end{array}$ & \\
Kriteria 5 & \\
$\begin{array}{l}\text { Perusahaan tidak mengalami } \\
\text { transaksi merger, akuisisi, } \\
\text { restruktirisasi dan perubahan } \\
\text { kelompok usaha selama } \\
\text { periode penelitian yaitu tahun } \\
\text { 2010 - 2014. Sebab hal } \\
\text { tersebut dapat membuat hasil } \\
\text { perhitungan menjadi bias }\end{array}$ & \\
\hline $\begin{array}{l}\text { Jumlah Target Populasi } \\
\text { Jumlah Populasi 117 x 5 }\end{array}$ \\
\hline
\end{tabular}

Sumber : Data yang sudah diolah

\subsection{Statistik Deskriptif}

Variabel dependen dalam penelitian ini adalah asimetri informasi, yang di ukur dengan bid - ask spread. Variabel independen dalam penelitian ini ada dua yaitu konservatisme akuntansi yang dikukur dengan menggunakan accrual base dan good corporate governance yang diukur dengan kepemilikan manajerial, kepemilikan institusional, komite audit, komisaris independen, ukuran dewan komisaris dan ukuran dewan direksi.

Dalam tabel 4.2 disajikan perhitungan statistik deskriptif dari masing - masing variabel selama periode penelitian yaitu mulai tahun 2010 sampai dengan 2014 dan juga perhitungan statistik deskriptif yang meliputi nilai maksimum, minimum, rata - rata dan standart deviasi.
Rata - rata variabel bid - ask spread, selama periode penelitian adalah 0,6374, dengan nilai tertinggi sebesar 1,97 pada perusahaan Surya Toto Indonesia, Tbk dan nilai terendah ada pada 8 perusahaan diantaranya adalah Alaska Industrindro, Tbk . Rata - rata variabel accrual base selama periode penelitian adalah 265.476.834.972, dengan nilai tertinggi sebesar 26.153.538.030.000 pada perusahaan Polychem Indonesia, Tbk dan nilai terendah sebesar (24.021.852.690.000) pada perusahaan Argo Pantes, Tbk. Rata - rata variabel kepemilikan manajerial selama periode penelitian adalah 2,8977 , dengan nilai tertinggi sebesar 46,41 dan nilai terendah sebesar 0 . Rata - rata variabel kepemilikan institusional selama periode penelitian adalah 72,5728 , dengan nilai tertinggi sebesar 100 dan nilai terendah 0 . Rata - rata variabel komite audit selama periode penelitian adalah 0,7487 , dengan nilai tertinggi sebesar 1 dan niali terendah sebesar 0 . Rata - rata variabel komisaris independen selama periode penelitian adalah 1,5128, dengan nilai tertinggi sebesar 4 dan nilai terendah sebesar 0 . Rata - rata variabel ukuran dewan komisaris selama periode penelitian 
adalah 4,1949, dengan nilai tertinggi sebesar 13 dan nilai terendah sebesar 2 . Rata - rata variabel ukuran dewan direksi selama periode penelitian adalah 4,8205, dengan nilai tertinggi sebesar 13 dan nilai terendah sebesar 2 .

Tabel 3. Statistik Deskriptif

\begin{tabular}{|l|l|l|l|c|}
\hline \multicolumn{1}{|c|}{ VARIABEL } & \multicolumn{1}{|c|}{ MINIM } & \multicolumn{1}{|c|}{ MAX } & \multicolumn{1}{c|}{ MEAN } & \multicolumn{1}{c|}{ SD } \\
\hline $\begin{array}{l}\text { KONSERV } \\
\text { ATIS }\end{array}$ & $\begin{array}{l}24.021 .85 \\
2.690 .000)\end{array}$ & $\begin{array}{l}26.153 .538 .030 .0 \\
00\end{array}$ & $\begin{array}{l}265.476 .834 .9 \\
72\end{array}$ & $\begin{array}{l}2.038 .441 . \\
871.131\end{array}$ \\
\hline ASIMETRIS & 0 & 1,97 & 0,6374 & 0,36362 \\
\hline $\begin{array}{l}\text { KEEMILIK } \\
\text { AN } \\
\text { MANAJERI } \\
\text { AL }\end{array}$ & 0 & 46,41 & 2,8977 & 7,24247 \\
\hline $\begin{array}{l}\text { KEEMILIK } \\
\text { AN }\end{array}$ & 0 & 100 & 72,5728 & 19,39456 \\
$\begin{array}{l}\text { INSTITUTI } \\
\text { ONAL }\end{array}$ & 0 & 1 & 0,7487 & 0,43805 \\
\hline $\begin{array}{l}\text { KOMITE } \\
\text { AUDIT }\end{array}$ & 0 & 13 & 4,8205 & 2,26655 \\
\hline $\begin{array}{l}\text { KOMISARI } \\
\text { S } \\
\text { INDEENDE } \\
\text { N }\end{array}$ & 0 & 4 & 1,5128 & 0,86221 \\
\hline $\begin{array}{l}\text { UKURAN } \\
\text { DEWAN } \\
\text { KOMISARI } \\
\text { S }\end{array}$ & 2 & 13 & 4,1949 & 1,80457 \\
\hline $\begin{array}{l}\text { UKURAN } \\
\text { DEWAN } \\
\text { DIREKSI }\end{array}$ & 2 & 13 & & \\
\hline
\end{tabular}

Sumber: Data Bursa Efek Indonesia

diolah

\subsection{Uji Asumsi Klasik}

Dalam pengujian normalitas semua variabel berdistribusi normal, hal ini terlihat dari gambar pada lampiran 10 yang menunjukkan titik - titik atau data terkumpul pada satu garis lurus. Dalam Kusnandar ( 2004 ) menyatakan bahwa prosedur pengujian hipotesis dengan statitstik $\mathrm{t}$ dan $\mathrm{F}$ berdasarkan atas asumsi kenormalan nilai - nilai galat. Namun demikian, analisis regresi bersifat 'robust' (tidak terpengaruh faktor pengganggu) terhadap asumsi kenormalan ini, artinya jika tidak terlalu serius menyimpang dari distribusi normal maka inferens tentang garis regresi dan koefisien regresi tidak terlalu terpengaruh. Hasil uji normalitas dapat dilihat pada lampiran 10.

Terkait dengan pengujian asumsi klasik lainnya, yaitu multikolinieritas, autokorelasi dan heterokedastisitas tidak ditemui adanya gejala - gejala penyimpangan atas asumsi tersebut dalam model yang diuji atau bisa dikatakan bahwa data dalam model regresi tersebut bebas asumsi klasik.

Hasil Uji Multikolinieritas, uji heterokidastisitas dan uji autokorelasi dapat dilihat pada lampiran 10

\section{a. Uji Multikolinieritas}

Uji multikolinieritas dimaksudkan untuk melihat apakah dalam model regresi ditemukan adanya korelasi diantara beberapa atau semua variabel independent. Salah satu cara untuk mengetahui ada tidaknya multikolinieritas adalah dengan melihat nilai VIF dan tolerance value. Dikatakan terjadi multikolinieritas jika 
nilai VIF > 10 dan tolerance value < 0,10 . Sebaliknya, jika nilai VIF $<10$ dan tolerance value $>0,10$ berarti tidak terdapat korelasi antara variabel independen yang satu dengan independen yang lain. Dari lampiran 10 dapat diketahui bahwa semua variabel independen mempunyai nilai VIF $<10$ dan tolerance value > 0,10, sehingga dapat disimpulkan bahwa tidak terjadi multikolinieritas.

Pengaruh konservatisme akuntansi terhadap asimetri informasi memiliki VIF sebesar 1 dan tolerance value sebesar 1. Sedangkan pengaruh mekanisme good corporate governance terhadap asimetri informasi masing masing adalah :

1. Kepemilikan manajerial memiliki nilai VIF sebesar 1,389 dan tolerance value sebesar 0,720

2. Kepemilikan institusional memiliki nilai VIF sebesar 1,355 dan tolerance value sebesar 0,738

3. Komite audit memiliki nilai VIF sebesar 1,007 dan tolerance value sebesar 0,993

4. Komisaris independen memiliki nilai VIF sebesar 2,128 dan tolerance value sebesar 0,470 .
5. Ukuran dewan komisaris memiliki nilai VIF sebesar 2,580 dan tolerance value sebesar 0,388

6. Ukuran dewan direksi memiliki nilai VIF sebesar 1,661 dan tolerance value sebesar 0,602

\section{b. Uji Autokorelasi}

Salah satu asumsi penting dari model klasik adalah bahwa gangguan yang berhubungan dengan observasi tidak berkorelasi atau tidak dipengaruhi oleh kesalahan atau gangguan yang berhubungan dengan pengamatan lain yang manapun. Untuk mengetahui ada tidaknya autokorelasi dilakukan dengan uji ACF plot, dimana bila ada nilai $r$ (et,et-k) malampaui batas $0 \pm 2 / \sqrt{ } \mathrm{n}$ maka residual tidak saling independen. Seperti yang dapat dilihat pada lampiran 10, semua hasil perhitungan uji plot ACF berada dalam penerimaan, yang berarti didalam model tidak terdapat autokorelasi. Durbin-Watson berada di antara dU dan 4 minus dU yang berarti semua model tidak terjadi autokorelasi.

\section{c. Uji Heterokedastisitas \\ Uji ini dilakukan untuk menguji} apakah dalam model regresi terdapat varian yang tidak sama dalam kesalahan pengganggu dan cara yang digunakan untuk mendeteksi ada tidaknya heterokedastisitas adalah dengan uji 
Glejser. Berdasarkan lampiran 10 dapat dibandingkan t hitung dengan t tabel, dimana $t$ hitung lebih kecil dari t tabel. Hal ini berarti bahwa tidak terjadi heterokedastisitas dalam model yang digunakan. Pengaruh konservatisme akuntansi terhadap asimetri informasi memiliki tingkat signifikansi sebesar 0,053 yang menandakan bahwa tidak terjadi heterokedastisitas.

\section{PENUTUP}

\subsection{Kesimpulan}

Penelitian ini mencoba menguji pengaruh konservatisme akuntansi dan mekanisme good corporate governance terhadap asimetri informasi. Berdasarkan beberapa hasil penelitian terdahulu konservatisme akuntansi dan good corporate governance memiliki pengaruh terhadap asimetri informasi. Penelitian ini dilakukan di perusahaan manufaktur yang terdaftar di Bursa Efek Indonesia (BEI) selama periode penelitian 2010 sampai dengan 2014.

Dari penelitian didapatkan kesimpulan

1. Konservatisme akuntansi tidak berpengaruh terhadap asimetri informasi pada perusahaan manufaktur yang terdaftar di Bursa Efek Indonesia. Penerapan prinsip konservatif dapat konservatisme tidak dapat mengurangi asimetri informasi dengan cara memberikan batasan kepada manajemen dalam menggunkan informasi yang mereka miliki.

2. Kepemilikan manajerial, kepemilikan institusional, komisaris independen, ukuran dewan komisaris dan ukuran dewan direksi tidak memiliki pengaruh terhadap asimetri informasi

3. Komite audit memiliki pengaruh terhadap asimetri informasi

4. Mekanisme good corporate governance tidak memiliki pengaruh terhadap asimetri informasi. peneraan good corporate governance pihak manajemen perusahaan akan lebih penuh pertimbangan dan lebih berhati - hati terhadap berbagai kebijakan akuntansi yang akan mereka ambil, hal ini untuk mencoba memastikan bahwa ketidakpastian dan risiko yang inheren dalam lingkungan bisnis sudah cukup dipertimbangkan.

\subsection{Saran}

1. Dalam penelitian ini menggunakan perusahaan 
manufaktur sebagai sampel, sehingga tidak dapat digeneralisasikan pada jenis perusahaan seperti perbankan, transportasi atau telekomunikasi. Oleh karena itu, disarankan untuk penelitian selanjutnya menggu nakan sampel seluruh perusahaan yang terdaftar di Bursa Efek Indonesia (BEI) secara general.

2. Penelitian ini hanya mengamati periode yang relatif pendek yaitu 5 tahun. Maka disarankan untuk penelitian selanjutnya mengamati periode penelitian yang lebih panjang agar diperoleh hasil yang berbeda dengan hasil penelitian sebelumnya.

3. Penggunaan kurs yang ada, hendaknya menggunakan kurs tengah BI per periode. Karena dalam penelitian ini, sebagian kecil laporan keuangan menggunakan mata uang dolar dan dalam penelitian ini menggunakan perkiraan kurs akhir tahun.

\section{DAFTAR PUSTAKA}

Atiqah. 2008. Corporate Governance, Pengungkapan Sukarela, dan Asimetri Informasi. Jakarta:
Fakultas Ekonomi Universitas Indonesia.

Basu, S. 1997. The Conservatism Principle and the Asymmetric Timeliness of Earnings. Journal of Accounting and Economics. (Vol. 24) p: 3-37

Boediono, SB., Gideon. 2005. Kualitas Laba: Studi Pengaruh Mekanisme Corporate Governance dan Dampak Manajemen Laba dengan Menggunakan Analisis Jalur. Makalah Simposium Nasional Akuntansi V111. Solo, 15-16 September

Dwiputro, Dibyo. 2010. Hubungan Antara Konservatisme Akuntansi dengan Konflik Antara Pemegang Saham dan Kreditur Terkait Kebijakan Deviden pada Perusahaan Manufaktur di Indonesia. Depok: Fakultas Ekonomi Universitas Indonesia

Faisal. Analisis Agency Cost, Struktur Kepemilikan dan Mekanisme Corporate Governance. Makalah Simposium Nasional Akuntansi V11. Denpasar-Bali, 2-3 Desember, Hal: 197-208

Givoly, D., Hayn, C., 2000. The Changing Time-Series Properties of Earnings, Cash Flows and Accruals: Has Financial Reporting Become More Conservative?. Journal of Accounting and Economics. 29: 287-320 
Haniati,Sri dan Fitriany. 2010. Pengaruh Konservatisme Terhadap Asimetri Informasi Dengan Menggunakan Beberapa Model Pengukuran Konservatisme. Simposium Nasional Akuntansi XIII. Purwokerto

Hastuti, Theresia, Dwi. 2005. Hubungan Antara Good Corporate Governance dan Struktur Kepemilikan dengan Kinerja Keuangan. Makalah Simposium Nasional Akuntansi V111. Solo, 15-16 September

Jensen, M., dan W. Meckling. 1976. Theory of the Firm: Managerial Behavior, Agency, and Ownership Structure. Journal of Financial Economics: $305-360$

Kanagaretman, Kiridaran., Lobo. G.J., Whalen D.J. 2007. Does good corporate governance reduce information asymmetry around quarterly earnings announcements?. Journal of Accounting and Public Policy. 26: 497-522

Khomsiyah. 2007. Makalah Seminar: Evaluasi Penerapan Good Corporate Governance di Indonesia. Himpunan Mahasiswa Jurusan Akuntansi UK.Petra, Surabaya

Lafond, Ryan., Watts, R.L. 2006. The Information Role of Conservative Financial Statements. The Accounting Review :447-478
Penman, S. H., dan X. J. Zhang. 2002. Accounting Conservatism: The Quality of Earnings and Stock Returns. The Accounting Review. 77 (2): 237-264

Scott, William R., 2000. Financial Accounting Theory. Second Edition. Canada: Prentice Hall

Ujiyantho, Muh. Arief, dan Bambang Agus Pramuka. 2007. Mekanisme Corporate Governance, Manajemen Laba dan Kinerja Keuangan. Makalah Simposium Nasional Akuntansi X. Makassar, 26-28 Juli.

Wardhani, Ratna. 2008. Tingkat Konservatisme Akuntansi Di Indonesia Dan Hubungannya Dengan Karakteristik Dewan sebagai Salah Satu Mekanisme Corporate Governance. Simposium Nasional Akuntansi. Pontianak

Watts, R, 2003, Conservatism in Accounting: Explanations and Implications, Accounting Horizon (September): 207-221 